\title{
Resources for a healthy diet: school meals
}

\author{
Javier Aranceta Bartrina ${ }^{1,2} *$ and Carmen Pérez-Rodrigo ${ }^{2}$ \\ ${ }^{1}$ Human Nutrition and Dietetics, University of Navarra, Spain \\ ${ }^{2}$ Community Nutrition Unit, Bilbao Department of Public Health, Luis Briñas, 18, 4th Floor, E-48013 Bilbao, Spain
}

\begin{abstract}
School meals have changed during the last decades. The traditional service style with on-site food preparation has shifted towards catering delivery services. Vending machines, school cafeterias and other ways of food distribution are widely used in many schools, particularly in secondary schools. From a health promotion approach, the quality and quantity of food and beverages consumed while in school have an enormous potential impact on the health and well-being of young people. Most children spend a significant part of their lives in school. Additionally, school meals supply 30-35\% of daily energy intake and provide an important contribution to nutrient intake. School life is a critical period in the acquisition and practice of healthy behaviours. Environmental interventions in schools, to increase availability and access to healthy foods such as fruit and vegetables, have proved to be effective. School meals should make high-quality foods available which allow nutrient requirements to be met, consistent with dietary guidelines and offering a positive nutritional experience. School meals should be part of the educational process in the life of the school.
\end{abstract}

School meals: Children: Health promotion: Monitoring: Healthy eating

In most developed countries, the catering sector has experienced important developments due to rapid social changes over the last decades. Eating out and take-away practices have evolved slowly in Mediterranean European countries, such as Spain (Federación Europea de la Restauración Colectiva, 1994; Datamonitor, 2005). However, nowadays catering corporations have increased as much as in any other European country, both in the commercial sector and as providers of services to social and institutional organizations.

Despite schedules for working hours tending to fit new demands and to facilitate the combination of a working and a family life, in Mediterranean countries the early afternoon meal is still the most important meal of the day. On average, in these countries lunch provides $30-35 \%$ of the daily intake of energy, protein and most nutrients (Alberti-Fidanza et al. 1999; SerraMajem \& Aranceta, 2002) and is usually a hot meal. Increasing numbers of women entering the workforce and a continuing trend towards settling housing areas in the surroundings of towns and cities rather than in the city centre, far away from the workplace, have substantially contributed to these changes.

Recent data in Spain suggest that more than $20 \%$ of school children in the country usually eat in schools as clients of school meals services (Serra-Majem \& Aranceta, 2002). The number of schools offering school meals has increased considerably over the last years in Spain. According to the Department of Statistics at the Spanish Ministry of Education, in the school year 2002-2003, $22 \%$ of the existing primary, secondary schools and kindergarten offered school meals (Ministerio de Educación, Cultura y Deporte, 2004).

\section{School meals in a health-promoting context}

From a health promotion approach, the quality and amount of food and beverages consumed while in the school have an enormous potential impact on the health and well-being of young people (Pérez-Rodrigo et al. 2001). Healthy eating and regular physical activity are essential for growth and development, helping young people to feel good, perform better at school and avoid developing risk factors which may lead to major chronic diseases and premature death.

Most children in Europe and the developed countries attend school for at least 10 years, approximately 9 months per year and 5 days a week, which is a significant proportion of a major period for growth and development. Moreover, the contribution of energy intake with school meals to total daily energy intake is within the range of $30-35 \%$ and also provides an important supply of nutrients (Gordon et al. 1995).

Additionally, the cultural impact as well as the potential influence of school meals in the educational and socialization processes should be considered (American Dietetic Association, 1999). School life is a critical period for acquiring and practising healthy behaviours and the school setting provides a valuable opportunity to influence health through policy measures, education and food provision (Birch \& Fisher, 1998; American Dietetic Association, 1999; Aranceta Bartrina, 2001; Pérez-Rodrigo et al. 2001; Story et al. 2002). Environmental interventions in schools, such as increasing the availability of and access to healthy foods such as fruit and vegetables, have proved to be effective (Perry et al. 2004).

Overall, there is a wide variation within and between countries, as well as between age groups, in how food is made available, for example, canteens, tuck shops, vending machines, etc. In some countries there are regulations regarding the quality of the menu offered in school meals, in terms of nutrient content or consistency with national dietary guidelines (Dixey et al. 1999; de Boer, 2005). However, in most places existing regulations only refer to the hygienic aspects of food quality, food preparation and delivery, as well as administration. 
School meals should make high-quality foods available which allow nutrient requirements to be met, consistent with dietary guidelines and offering a positive nutritional experience. Furthermore, school meals should be part of the educational process, providing a valuable opportunity to practise what children learn in the school, share tasting experiences with their peers and teachers while they learn from them, supported by policies that facilitate a positive school environment (Dixey et al. 1999; Aranceta Bartrina, 2001; Pérez-Rodrigo et al. 2001). This includes a comfortable room, pleasant atmosphere and plenty of time to enjoy healthy food in the school, either food provided by the school or brought from home (Fig. 1). However, daily practice shows this is not always the case (Raizman et al. 1994; Aranceta \& Pérez Rodrigo, 1996; Meyer, 2000; Aranceta Bartrina et al. 2004). Poor motivation and awareness, lack of space, busy schedules, inadequate room, few resources and poor training of food service staff are some conditioning factors of the real picture (Raizman et al. 1994; Aranceta \& Pérez Rodrigo, 1996; Brown et al. 1997; Bergman et al. 2000; Meyer, 2000; Aranceta Bartrina et al. 2004).

\section{Planning and organization}

Planning school meals should consider the different dimensions involved, i.e. nutritional, educational and social. All elements need to be arranged to satisfy the needs of endusers: the quality and quantity of foods served; the menu and food preparation techniques; the organization of the service and even physical elements such as cutlery and dinner service, kitchen environment and dining-room (Aranceta \& Pérez Rodrigo, 2001).

Whenever the food service is based on a single menu offer, as is the case in Spain and other Southern European countries, careful professional dietary advice and menu planning should be guaranteed to ensure nutrition adequacy and consistency with dietary guidelines (Aranceta \& Pérez Rodrigo, 2001). This is particularly relevant when school meals are used to provide a security allowance for nutrients identified to be inadequately supplied and in at-risk groups. However, it is inadvisable for the energy and fat content of school meals to be too high. Children need to work in the afternoon and such practices may induce sleep and lower school performance (Aranceta \& Pérez Rodrigo, 2001).

The main structure of the menus when based on a single meal offer could consist of alternating combinations of legumes, vegetables, rice, pasta or potatoes; low-fat meat, poultry, fish or egg-based preparations, with a side dish of salad or vegetables. Dessert will preferably consist of a dairy product and/or fresh fruit. Cakes and buns rich in fats and sugar are not recommended as part of school menus (Aranceta \& Pérez Rodrigo, 2001).

Whatever way the service is provided, nutrient-based standards and recommendations for school meals are desirable to guide caterers and ensure adequate food and beverages are provided in schools. These should include information on food-based guidelines, as well as portion sizes.

School meals must use simple food preparations, which help children to become familiar with new food items, new tastes and textures. Children's food likes and dislikes should be considered when designing menu plans, although nutritional adequacy criteria and educational added value should also be considered.

\section{Monitoring of school meals}

Monitoring and evaluation are important facts to improve the quality of the service and its potential contribution to promoting the health and well-being of adults and children in the school (Pérez-Rodrigo et al. 2001). Table 1 shows a number of aspects which should be included in the evaluation, with the main focus on the needs of users. Qualitative and quantitative aspects of food and the food service along with environmental conditions surrounding it should be considered. Participation of the different actors involved, namely students, teachers, school managers, parents as well as food service staff, and training opportunities

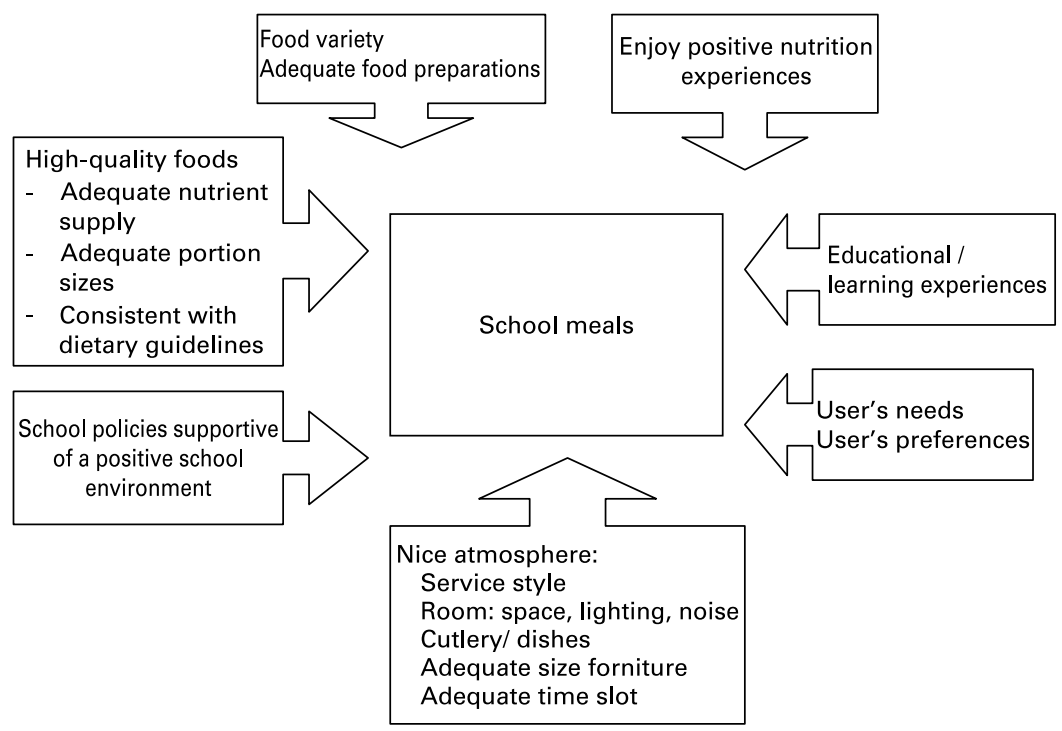

Fig. 1. Elements to be considered in school meals in a health-promoting context. 
Table 1. Monitoring the quality of food service in schools

\begin{tabular}{lll}
\hline & Qualitative evaluation & Quantitative evaluation \\
\hline Methods & Focus groups & Questionnaires \\
& Personal interviews & Dietary assessment methods \\
The users & Pbservations & Health and nutrition status indicators \\
& Perceived needs & Dietary intake at school \\
& Special needs & Dietary intake out of school \\
The food & Perceived quality and variety of food supply & Food preferences \\
& Perceived quantity of food supply & Users with special needs \\
& Perceived pricing & Quality of food supply \\
& Food safety issues & Portion sizes \\
& & Variety of foods \\
& & Food preparation \\
& Quality/adequacy of the physical environment & Pricing and subsidies \\
Perceived quality of food service style & Food safety issues \\
& Organization of food service \\
& Quality/adequacy of the physical environment: \\
& Size of tables and chairs \\
& Quality of dishes and cutlery \\
& Room decoration \\
& & Room lighting \\
& Environmental noise \\
& & Time available for food consumption
\end{tabular}

for those with major responsibility for organizing and providing the service, are important strategies for quality improvement.

A combination of qualitative techniques, such as focus groups, personal interviews and observations, and quantitative methods by means of questionnaires as well as dietary assessment tools is desired. Other nutrition and health indicators can be considered when required.

Results of the School Meals Surveillance and Monitoring Program of Bilbao reflect that the aesthetic characteristics of the room, such as lighting and environmental noise, during meals deserve the lowest scores on perceived quality of the service, while food service staff score the highest (Fig. 2; Aranceta \& Pérez Rodrigo, 1996).

In the Dime Como Comes study in Spain, $55 \%$ of boys and $40 \%$ of girls aged 12-16 years reported eating only half of the portion served, citing dislike for taste (50\%) and inadequate temperature $(10 \%)$ as the main arguments. The same study showed that vegetables and fish were offered less frequently than other food groups in school meals (Fig. 3; Aranceta Bartrina, 2001).

The evaluation of the US Department of Agriculture School Meals and Breakfast Program and other European programmes showed their contribution to total daily intake

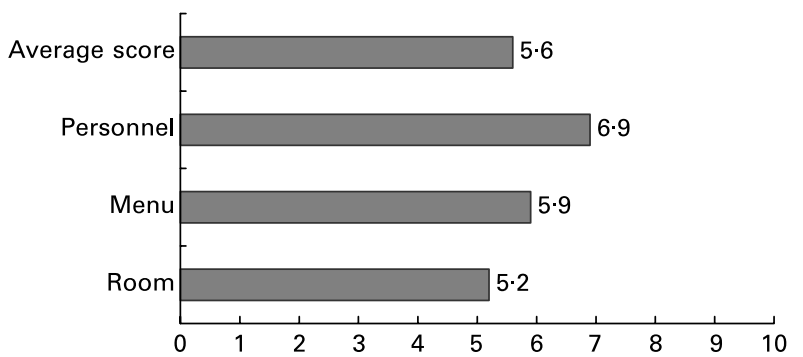

Fig. 2. Evaluation of school meals in Bilbao, Spain. Average and selected dimensions of perceived quality score of school meals. and the potential for intervention (Gordon et al. 1995). Participation rates and acceptance of the food offered are important conditioning factors for success, but this can also be improved by food service style (in particular a family style of serving the food; Donnelly et al. 2000), variety and quality of the food offered, as well as presentation and the texture of the food.

Identifying problems and needs is the first step in any planning attempt. It would be desirable to develop a monitoring system which would enable assessment of the current situation and allow for follow-up. Easy-to-use evaluation tool kits and checklists could help in setting this process at the school level. Information collected should try to provide answers to questions such as who eats at school (students, teachers, parents); whether the special needs of users have been considered; what kind of foods and beverages are available; the aesthetics of the eating area, the allocated time of the meal, organization of the service and the physical environment, etc.

Policy and organizational issues influence the service. Hence, it would be advisable to consider those in the monitoring system too, in terms of the nature and content of existing policies and regulations. Where not existing, the development of school nutrition policies for the provision of food in schools should be encouraged, fostering active participation of the different sectors involved.

Information and awareness at all levels help to change attitudes and enforce environmental action. This means that advocacy strategies are required at national, regional and local levels to introduce school meals into the agenda setting of education authorities, health authorities, school health services, catering companies, local administration and other relevant bodies.

At the school level, management staff, food service personnel, teachers, students and families are the targets for involvement. Training opportunities and support for kitchen or school meals personnel in their crucial work, providing families with 


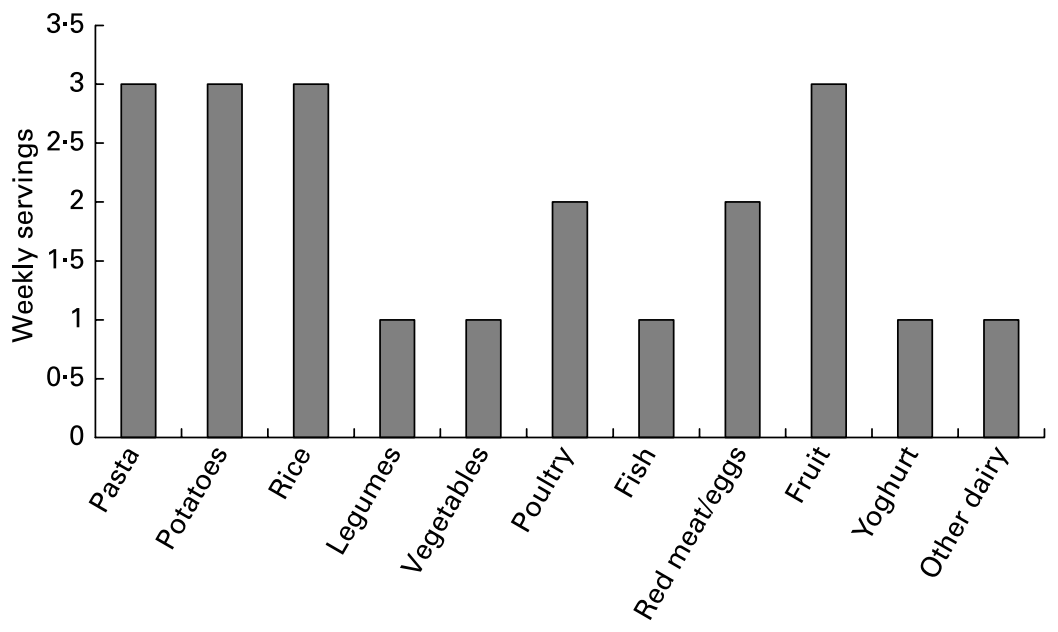

Fig. 3. Food frequency servings in school meals in Spain. The Dime Como Comes study.

adequate information regarding school meals and organizing occasions where parents can take part in school life, are important strategies to consider.

The Fifty-seventh World Health Assembly held in May 2004 provided a logical step for all Member States. Resolutions following that meeting encourage national health authorities to develop and implement national nutrition action plans, which include food-based dietary guidelines (World Health Organization, 2004).

\section{References}

Alberti-Fidanza A, Fidanza F, Chiuchiu MP, Verducci G \& Fruttini D (1999) Dietary studies on two rural Italian population groups of the Seven Countries Study. 3. Trend of food and nutrient intake from 1960 to 1991. Eur J Clin Nutr 53(11), 854-860.

American Dietetic Association (1999) Statement. Promoting Healthy Eating Behaviors: The Role of School Environments. Washington, DC: USDA Food, Nutrition and Consumer Services.

Aranceta Bartrina J (2001) Nutrición Comunitaria, $2^{\mathrm{a}}$ ed. Barcelona: Masson.

Aranceta J \& Pérez Rodrigo C (1996) Consumo de Alimentos y Estado Nutricional de la Población Escolar de Bilbao. Guías Alimentarias Para la Población Escolar. Bilbao: Area de Salud y Consumo, Excmo, Ayuntamiento de Bilbao.

Aranceta J \& Pérez Rodrigo C (2001) Alimentación colectiva en centros docentes. Tratado de Nutrición Pediátrica, pp. 1115-1128 [R Tojo, editor]. Barcelona: Doyma.

Aranceta Bartrina J, Pérez Rodrigo C, Serra-Majem Ll \& Delgado Rubio A (2004) Hábitos alimentarios de los alumnos usuarios de comedores escolares en España. Estudio 'Dime Como Comes'. Aten Primaria 33, 131-139.

Bergman EA, Buergel N, Joseph E \& Sanchez A (2000) Time spent by schoolchildren to eat lunch. J Am Diet Assoc 100, 696-698.

Birch LL \& Fisher JO (1998) Development of eating behaviors among children and adolescents. Pediatrics 101, Suppl., 539-549.

Brown NE, Gilmore SA \& Dana JT (1997) Perceptions of food quality and dining environment in schools. School Food Serv Rev 21, $38-45$.
Datamonitor (2005) Trends \& Behaviors in Eating Out 2005. http:// www.mindbranch.com/products/r313-8220.html (accessed April 2005).

de Boer F (2005) Eating at school. A European study. In Eating at School - Making Healthy Choices, pp. 35-44. Strasbourg: Council of Europe.

Dixey R, Heindl I, Loureiro I, Pérez-Rodrigo C, Snel J \& Warnking P (1999) Healthy Eating for Young People in Europe. Nutrition Education in Health Promoting Schools. Copenhagen: European Network of Health Promoting Schools.

Donnelly JE, Jacobsen DJ, Legowski P \& Johnson S \& McCoy P (2000) Family-style foodservice can meet US dietary Guidelines for elementary school children. J Am Diet Assoc 100, 103-105.

Federación Europea de la Restauración Colectiva (1994) La restauración colectiva en Europa en el año 2000. Caternews 15, 13-14.

Gordon AR, Devaney BL \& Burghardt JA (1995) Dietary effects of the national school lunch program and the school breakfast program. Am J Clin Nutr 61, 221S-231S.

Meyer MK (2000) Top predictors of middle/junior high school student's satisfaction with school foodservice and nutrition programs. J Am Diet Assoc 100, 100-103.

Ministerio de Educación, Cultura y Deporte (2004) Estadística. http:// www.mec.es/estadística (accessed February 2005).

Pérez-Rodrigo C, Klepp KI, Yngve A, Sjöstrom M, Stockley L \& Aranceta J (2001) The school setting: an opportunity for the implementation of dietary guidelines. Public Health Nutr 4, 717-724.

Perry C, Bishop BD, Taylor CA, et al. (2004) A randomized school trial of environmental strategies to encourage fruit and vegetable consumption among children. Health Educ Behav 31, 63-76.

Raizman DJ, Montgomery DH, Osganian SK, et al. (1994) CATCH: food service program process evaluation in a multicenter trial. Health Educ Q Suppl. 2, S51-S71.

Serra-Majem L \& Aranceta Bartrina J (eds) (2002) Alimentación Infantil y Juvenil. Estudio enKid, vol. 3. Barcelona: Masson.

Story M, Neumark-Sztainer D \& French S (2002) Individual and environmental influences on adolescent eating behaviors. $J \mathrm{Am}$ Diet Assoc 102, S40-S51.

World Health Organization (2004) Global Strategy on Diet, Physical Activity and Health. Fifty-seventh World Health Assembly, Agenda Item 12.6. http://www.who.int/gb/ebwha/pdf_files/WHA57/ A57_R17-en.pdf (accessed June 2004). 